\title{
Performance of Cassava (Manihot esculanta. Crantz) Varieties at Different Areas of South Omo, Southern Ethiopia
}

\author{
Mohammed Awel \\ Jinka Agricultural Research Center Department of Crop Science Research Case Team, Southern Agricultural Research Institute, Jinka, \\ Ethiopia \\ Email address: \\ mohammedawel27@gmail.com

\section{To cite this article:} \\ Mohammed Awel. Performance of Cassava (Manihot esculanta. Crantz) Varieties at Different Areas of South Omo, Southern Ethiopia. \\ Journal of Plant Sciences. Vol. 8, No. 3, 2020, pp. 67-70. doi: 10.11648/j.jps.20200803.13
}

Received: June 2, 2020; Accepted: June 24, 2020; Published: July 28, 2020

\begin{abstract}
A field experiment involving four improved cassava (manihot esculanta, crantz) varieties and one local check was carried out at four different locations of South Omo zone (Kurea, Jinka on station, Geza and Shepi Kebelles) during the 2018 to 2019 cropping seasons under rain fed conditions to identify the best performing variety/ies to the target areas of South Omo zone. The cassava varieties included in the field experiment were four improved (Kelo, Qulle, Hawassa-04, Chancho) and a local check. The experimental design was a randomized complete block design (RCBD) with three replications. Growth, yield and yield components were studied. The result showed that plant height was significantly affected by variety while number of primary and secondary branch was not significantly influenced by variety. Total root number per plant, tuber weight and total yield per hectare also showed a significance difference among varieties. The highest total root yield per hectare (24.77 $\mathrm{t} / \mathrm{ha})$ was recorded from Hawassa-04 where as Chancho, Kelo, Qule and local check show no significance difference among each other. Therefore, it can be concluded that use of the improved cassava varieties such as Hawassa-04 is advisable and could be appropriate for cassava production in the test area even though further testing is required to put the recommendation on a strong basis.
\end{abstract}

Keywords: Root Yield, Growth Parameters, Cassava Variety, Yield Components

\section{Introduction}

Cassava (Manihot esculenta Crantz) is an important staple crop recognized as a $21 \mathrm{st}$ century crop mostly for smallholder farmers [1, 2]. According to Food and Agriculture Organization of the United Nation (FAO), it is one of some 100 species of tree, shrub and herbs of the genus Manihot believed to have been introduced from northern Argentina to the United States of America [2]. Other studies opined that cassava has several centers of origin beginning from southern edge of the Brazilian Amazon [3, 4].

Cassava (Manihot esculenta Crantz) is cultivated throughout the lowland tropics, typically between $30^{\circ} \mathrm{N}$ and $30^{\circ} \mathrm{S}$ of the equator, in areas where the annual mean temperature is greater than $18^{\circ} \mathrm{C}$ [5]. Cassava is an important crop in Africa where it serves as a famine reserve crop, industrial raw material and livestock feed [6]. The crop stores well in the soil, has high starch productivity and performs relatively well in low fertility soils and marginal areas [7]. The diverse uses of cassava largely explain its popularity in the tropics [7]. In Africa most cassava produced is used for food consumption, with $50 \%$ in processed form, and $38 \%$ in the fresh and/ or boil form; $12 \%$ is used for animal feed. Despite its enormous production potential, adaptation to a great diversity of environments, its recognized tolerance of biotic and abiotic constraints to production, and its diversity of uses, cassava has not yet been managed to fully develop its potential in tropical agriculture due to numerous factors. Among the factors that constrained the production of cassava is lack of early maturing, high yielding and low hydrogen cyanide containing varieties [8].

According to FAO estimates, 291,992,646 tons of cassava were produced worldwide in 2017. Africa accounted for $57 \%$, Asia for $32 \%$, and others $11 \%$ of the total world 
production. In 2017, Nigeria produced 59.4 million tones making it the world's largest producer followed by Congo DR, Thailand, Indonesia and Brazil with 31.5, 30.9.19 and 18.8 million tons, respectively. In terms of area harvested, a total of $26,342,330$ hectares was planted with cassava throughout the world in 2017; about $64 \%$ of this was in subSaharan Africa. The average yield in this year was 11.08 tons per hectare [9].

In Ethiopia, it is mainly cultivated by small resource poor farmers on smallholding plots of land. It is both a food security crop and a source of household income. It is increasingly becoming a source of industrial raw material for production of starch, ethanol, waxy starch, bio-plastics, glucose, bakery and confectionery products, glue, among others [10]. In Ethiopia, cassava generally is being grown in almost all parts of the country. But bulk of its production is situated in south, south western and western parts of the country.

The average total coverage and production of cassava per annum in Southern region of Ethiopia is 195,055 hectares with the yield of 501,278.5 tones indicating the average productivity of cassava in the country is not more than 25 ton per hectare [11]. Which is by far lower than the yield obtained by other tropical countries such as Nigeria that recorded 35.00 tons per hectare per year [1].

In Ethiopia, most of the varieties produced were local farmers' varieties which are low yielding, late maturing, bitter type and containing high hydrogen cyanide [12]. To alleviate these problems, a number of research activities focusing on crop variety improvement were conducted in different agro-ecological locations. Hence evaluation of four improved cassava varieties and one local check were conducted at different locations of South Omo zone as a result, promising varieties with regard to storage root yield per a given period from a given area of land were obtained. Therefore, this paper aimed to show the performance of different improved cassava varieties under different agro ecological conditions of southern Ethiopia.

Table 1. World (regions) cassava production ('000 tonnes).

\begin{tabular}{lllllll}
\hline & $\mathbf{2 0 1 2}$ & $\mathbf{2 0 1 3}$ & $\mathbf{2 0 1 4}$ & $\mathbf{2 0 1 5}$ & $\mathbf{2 0 1 6}$ \\
\hline World & 277,683 & 278,454 & 292,054 & 295,244 & 296,043 \\
Africa & 158,033 & 159,836 & 169,595 & 173,343 & 177,736 \\
America & 30,487 & 30,519 & 32,338 & 32,436 & 30,267 \\
Asia & 88,953 & 87,849 & 89,867 & 89,122 & 87,798 \\
Caribbean & 957 & 1,134 & 1,256 & 1,528 & 28,993 & 1,481 \\
Oceania & 210 & 250 & 253 & 252 & 241,038 \\
\hline
\end{tabular}

Source: FAOSTAT, 2019

\section{Materials and Methods}

\subsection{Description of the Study Area}

The experiment was conducted on four different locations namely Jinka on station, Geza, Shepi and Kurea kebelle of South Omo zone. The long term weather data for these area revealed that the maximum and minimum monthly average temperature of the center is $31.55^{\circ} \mathrm{C}$ and $19.55^{\circ} \mathrm{C}$, respectively; whereas, the maximum and minimum monthly average temperature of the growing periods was $23.576^{\circ} \mathrm{C}$ and $10.622^{\circ} \mathrm{C}$, respectively. The long term rainfall data for the area showed that the mean annual rainfall of the area is $1774.67 \mathrm{~mm}$; while the mean monthly rainfall of the area for the growing seasons was $151.7188 \mathrm{~mm}$. Rainfall pattern of the area over the years have been bi-modal with peaks around September and October and spans from February to November. The experiment was conducted during the 2018 to 2019 cropping seasons under rain fed conditions.

\subsection{Treatments and Experimental Design}

The experiment was executed by using four improved cassava varieties and one local check. The improved varieties were Awassa-04, Chancho, Qule and Kello. The field experiment was laid out in a randomized complete block design (RCBD) with three replications. The spacing was $1 \mathrm{mX} 1 \mathrm{~m}$ between plants and rows respectively. The gross plot area was $4 \mathrm{~m} \times 5 \mathrm{~m}, 20 \mathrm{~m}^{2}$.
Storage root yield and other yield related data such as root length, root girth, number of roots per plants and growth rate were taken from the net plot at harvesting except the growth rate which was taken in three months interval from planting. Data on the root length, root girth, number of roots per plants and growth rate were taken from randomly selected five plants. Whereas, the storage root yield data was taken from each plot in kilogram and converted into yield per hectare in ton by using the following formula:

$$
\text { Yield per hectare }=\frac{\text { yield per plot }(\mathrm{kg}) \times 10000 \mathrm{~m}^{2}}{20 \mathrm{~m}^{2} * 1000(\mathrm{~kg} / \mathrm{t})}
$$

Note that 1 ton(t) is equals to $1000 \mathrm{~kg}$.

Storage root yield was clustered into marketable, unmarketable and total yield. Marketable storage roots yield was referred to the yield of those roots weighting 100-500 g, storage roots not infected by disease and not infested by insect pests, whereas unmarketable storage root yield was referred to those roots weighting more than $500 \mathrm{~g}$ and less than $100 \mathrm{~g}$, storage roots infected by disease and infested by insect pests and miss shaped roots. Total storage root yield was the sum total of marketable and unmarketable root yields. The dry matter content of the varieties was taken after oven drying for $24 \mathrm{~h}$ at $110^{\circ} \mathrm{C}$ for consecutive dates until the weight was constant.

\subsection{Statistical Analysis}

Analysis of variance was performed using the GLM 
procedure of SAS Statistical Software Version 9.0 [13]. Effects were considered significant in all statistical calculations if the $\mathrm{P}$-values were $<0.05$. Means were separated using Fisher's Least Significant Difference (LSD) test.

\section{Result and Discussion}

Significant differences $(\mathrm{P}<0.05)$ were observed on parameters of plant height, canopy diameter, number of buds, root diameter, number of roots per plant, number of marketable roots, marketable yield, total yield and dry matter content (Table 2 and Table 3). The plant height ranged from $241.21 \mathrm{~cm}$ in Chancho variety to $243.50 \mathrm{~cm}$ in local check. Hawassa-04 variety record maximum canopy diameter $(281.67 \mathrm{~cm})$ while Chancho variety recorded minimum $(198.75 \mathrm{~cm})$. Maximum number of roots per plant (13.33) was recorded on variety Hawassa-04 with no significant difference over the variety Kelo (11.33) whereas minimum number of roots per plant was recorded on varieties Chancho (10.00), Qulle (9.00) and local check (8.33) with no significant difference among each other.

Table 2. Mean Square values for growth related parameters of four cassava varieties grown at South Omo, in 2018 to 2019.

\begin{tabular}{|c|c|c|c|c|c|c|c|c|}
\hline Source & DF & $\mathbf{P H}$ & CD & NB & NPB & NSB & RL & RD \\
\hline Treatment & 5 & $2474.97 *$ & $3092.08 *$ & 189.44* & $0.11 \mathrm{~ns}$ & $2.27 \mathrm{~ns}$ & $161.65 \mathrm{~ns}$ & 5.85 \\
\hline Block & 2 & 635.26 & 70.31 & 90.32 & 1.12 & 11.85 & 71.93 & 0.24 \\
\hline Error & 7 & 174.60 & 212.23 & 49.19 & 0.41 & 3.22 & 63.90 & 0.72 \\
\hline
\end{tabular}

$\mathrm{PH}=$ plant height, $\mathrm{CD}=$ canopy diameter, $\mathrm{NB}=$ number of buds, $\mathrm{NPB}=$ number of primary branch, $\mathrm{NSB}=$ number of secondary branch, $\mathrm{RL}=$ root length, $\mathrm{RD}=$ root diameter $*=$ significant $\mathrm{ns}=$ non significant

Table 3. Mean Square values for yield related parameters of five cassava varieties grown at South Omo, in 2018 to 2019.

\begin{tabular}{llllllll}
\hline Source & DF & NRPP & NMR & NUNMR & MY & UNMY & TY \\
\hline Treatment & 5 & $11.90^{*}$ & $54.77^{*}$ & $17.23 \mathrm{~ns}$ & $125.93 *$ & $0.75 \mathrm{~ns}$ & $120.57^{*}$ \\
Block & 2 & 1.25 & 6.07 & 0.20 & $5.26 \mathrm{~ns}$ & $0.04 \mathrm{~ns}$ & $4.97 \mathrm{~ns}$ \\
Error & 7 & 3.00 & 8.07 & 6.28 & 5.42 & 0.41 & 5.07 \\
\hline
\end{tabular}

$\mathrm{NRPP}=$ number of roots per plot, $\mathrm{NMR}=$ number of marketable roots, $\mathrm{NUNMR}=$ number of unmarketable roots, $\mathrm{MY}=$ marketable yield, $\mathrm{UNMY}=$ unmarketable yield, $\mathrm{TY}=$ total yield, $\mathrm{DM}=$ dry matter

Table 4. Combined mean plant height, canopy diameter, number of buds, number of primary branch, number of secondary branch, root length and root diameter of five cassava varieties grown at south omo.

\begin{tabular}{|c|c|c|c|c|c|c|c|}
\hline Variety & $\mathbf{P H}$ & CD & NB & NPB & NSB & RL & RD \\
\hline Hawassa 04 & $221.25 \mathrm{~B}$ & $281.67 \mathrm{~A}$ & $40.00 \mathrm{~A}$ & 3.00 & 8.17 & 58.33 & $9.04 \mathrm{~A}$ \\
\hline chancho & $195.65 \mathrm{C}$ & $198.75 \mathrm{D}$ & $32.67 \mathrm{AB}$ & 2.83 & 7.17 & 38.47 & $6.72 \mathrm{~B}$ \\
\hline kelo & $241.21 \mathrm{AB}$ & $216.67 \mathrm{CD}$ & $25.17 \mathrm{BC}$ & 3.00 & 8.00 & 49.27 & $6.02 \mathrm{~B}$ \\
\hline qulle & $207.80 \mathrm{BC}$ & $250.83 \mathrm{~B}$ & $18.83 \mathrm{C}$ & 2.67 & 7.00 & 50.53 & $5.73 \mathrm{~B}$ \\
\hline local & $243.50 \mathrm{~A}$ & $228.33 \mathrm{BC}$ & $28.67 \mathrm{ABC}$ & 3.17 & 9.17 & 44.80 & $5.73 \mathrm{~B}$ \\
\hline Significance & $*$ & $*$ & $*$ & ns & ns & ns & $*$ \\
\hline $\mathrm{SE} \pm$ & 7.62 & 8.41 & 4.04 & 0.36 & 1.03 & 4.61 & 0.49 \\
\hline CV (\%) & 5.68 & 6.19 & 24.13 & 21.78 & 22.73 & 16.56 & 12.80 \\
\hline
\end{tabular}

$\mathrm{PH}=$ plant height, $\mathrm{CD}=$ canopy diameter, $\mathrm{NB}=$ number of buds, $\mathrm{NPB}=$ number of primary branch, $\mathrm{NSB}=$ number of secondary branch, $\mathrm{RL}=$ root length, $\mathrm{RD}=$ root diameter $*=$ significant $n s=$ non significant

Yield and yield related traits also showed a significant difference $(\mathrm{P}<0.05)$ across locations (Table 5). Highest tuber yield was recorded on the variety Hawassa-04 (24.77 t/ha) and showed a significant difference over the tested varieties. In case of root dry matter varieties Kelo and Chancho recorded maximum dry matter, of 49.83 and 49.33 respectively, which is significant difference over the other varieties.

Average storage yield obtained from East African countries such as Kenya, Uganda and Tanzania in 2013 was 15.89, 12.02, 7.50 tons per hectare, respectively. Differences in cassava tuber yield are determined by several factors, such as number of tubers, tuber length and tuber weight per plant. [14] concluded that storage root number, storage root size and storage root diameter were the main yield components contributing to yield enhancement in cassava. As far as yield related traits are concerned, the value obtained directly concedes with the report of [15]. In his study, the highest storage root length obtained from the variety, Cuban White Stick was $40.46 \mathrm{~cm}$. In the same way, the highest storage root number per plant was obtained from the variety John LaMotte (7.78) which is similar to the value recorded from the current study (8.52).

The parameters number of primary branch, secondary branch, root length, number of non-marketable roots per plot and unmarketable yield per hectare showed no significant difference $(\mathrm{P}>0.05)$ among varieties (Table 2 and Table 3 ).

From this study variety Hawassa 04 which yields maximum yield as compared to the other varieties is recommended in terms of yield. In case of Dry matter content both varieties of Chancho and Kelo are recommended which were recorded maximum dry matter content with no significant difference among each other. 
Table 5. Combined mean number of roots per plant, number of marketable roots, number of unmarketable roots, marketable yield, unmarketable yield, total yield and dry matter of five cassava varieties grown at south Omo.

\begin{tabular}{|c|c|c|c|c|c|c|c|}
\hline Variety & NRPP & NMR & NUNMR & MY & UNMY & TY & DM \\
\hline Hawassa 04 & $13.33 \mathrm{~A}$ & $21.33 \mathrm{~A}$ & 5.67 & $23.77 \mathrm{~A}$ & 1.00 & $24.77 \mathrm{~A}$ & $44.83 B$ \\
\hline Chancho & $10.00 \mathrm{~B}$ & $15.00 \mathrm{~B}$ & 5.33 & 10.37B & 0.97 & 11.27B & $49.33 \mathrm{~A}$ \\
\hline Kelo & $11.33 \mathrm{AB}$ & $13.33 \mathrm{~B}$ & 9.00 & $11.00 \mathrm{~B}$ & 1.90 & 12.90B & $49.83 \mathrm{~A}$ \\
\hline Local & $8.33 \mathrm{~B}$ & $13.33 \mathrm{~B}$ & 3.33 & $9.47 \mathrm{~B}$ & 0.80 & $10.27 \mathrm{~B}$ & $44.67 \mathrm{~B}$ \\
\hline Significance & $*$ & * & ns & $*$ & ns & $*$ & $*$ \\
\hline $\mathrm{SE} \pm$ & 1.00 & 1.63 & 1.44 & 1.34 & 0.36 & 1.29 & 0.89 \\
\hline $\mathrm{CV}(\%)$ & 16.65 & 19.54 & 39.17 & 18.74 & 49.85 & 16.44 & 3.33 \\
\hline
\end{tabular}

\section{Conclusion}

In Ethiopia, most of the varieties produced were local farmers' varieties which are low yielding, late maturing,

bitter type and containing high hydrogen cyanide.

Significant differences $(\mathrm{P}<0.05)$ were observed on parameters of plant height, canopy diameter, number of buds, root diameter, number of roots per plant, number of marketable roots, marketable yield, total yield and dry matter content. The plant height ranged from $241.21 \mathrm{~cm}$ in Chancho variety to $243.50 \mathrm{~cm}$ in local check. Hawassa- 04 variety record maximum canopy diameter $(281.67 \mathrm{~cm})$ while Chancho variety recorded minimum $(198.75 \mathrm{~cm})$. Maximum number of roots per plant (13.33) was recorded on variety Hawassa-04 with no significant difference over the variety Kelo (11.33) whereas minimum number of roots per plant was recorded on varieties Chancho (10.00), Qulle (9.00) and local check (8.33). storage root number, storage root size and storage root diameter were the main yield components contributing to yield enhancement in cassava.

Using improved varieties of cassava could make an important contribution to increase agricultural production and productivity in areas like South Omo where there is low practice of using improved technologies such as improved crop varieties. To this end, use of improved cassava technologies such as improved varieties could be one of the alternatives to improve productivity by small farmers. However, the use of improved Cassava varieties is not yet studied in the area. Thus, this research work is initiated to investigate the impact of including improved Cassava varieties on the existing production system is of paramount important.

\section{References}

[1] Food and Agriculture Organization of the United Nations (FAO) Save and Grow: Cassava, A guide to sustainable production and intensification. Rome (2013).

[2] Droppelmann K., et al. "Cassava, the 21 st century crop for smallholders? Exploring innovations along the livelihood value chain nexus in Malawi”. Centre for Rural Development (SLE) Berlin, SLE Publication Series (2018): S 274.

[3] Allem, A. C. 2002. "The origins and taxonomy of cassava". In
R. J. Hillocks, J. M. Thresh \& A. C. Bellotti, eds. Cassava: Biology, production and utilization Wallingford, UK, CAB International. 1-16.

[4] Nassar NMA. "Conservation of the genetic resources of cassava (Manihot esculenta Crantz): determination of wild species location with emphasis on probable origin". Economic Botany 32.3 (1978): 311-320.

[5] Nassar N. M. A., \& Ortiz, R. (2007). Cassava improvement: challenges and Impacts. Journal Agricultural Science, 145, 163-171. http://dx.doi.org/10.1017/S0021859606006575

[6] Nkweke, F. I., Spencer, D. S. C., \& Lynam, J. K. (2002). The Cassava Transformation: Africa's Best-kept Secret. East Lansing, USA: Michigan State University Press.

[7] Hershey, C. (2010). Cassava breeding: theory and practice. A publication by Food and Agriculture Organisation (FAO), In Press.

[8] Tesfaye T., Atnafua B., Engida T., Getachew W., Tewodros M., Wubshet B. and Mesele G. (2016). Performance of cassva (Manihot esculenta crantz) clones in potential and low moisture stressed areas of Ethiopia.

[9] Food and Agriculture Organization of the United Nations (FAO). FAOSTAT Statistical Database, Statistical Division. Rome (2019).

[10] Tesfaye T, Getahun D, Ermias S, Shiferaw M, Temesgene A, Birhanu Y (2013). Current status, Potentials and challenges of Cassava production, processing, marketing and utilization: Evidence from Southern Ethiopia. Greener J. Agric. Sci. 3 (4): 262-270.

[11] SNNPR BoA (Southern Nationalities and Peoples Region, Bureau of Agriculture) (2014). Basic Agricultural Information Planning and programming Service, Hawassa, Ethiopia. Unpublished row data.

[12] Anshebo T, Tofu, Tsegaye E, Kifle A, Dagne Y (2004). New cassava varieties for tropical semi arid climate of Ethiopia. In: A proceedings of the 9th ISTRC-AB symposium 2004 Nairobi, Kenya. pp. 526-530.

[13] SAS. 2002. Statistical Analysis Systems SAS/STAT user's guide Version 9.0 Cary NC: SAS Institute Inc. USA.

[14] Ntawuruhunga P, Dixon A (2010). Quantitative variation and interrelationship between factors influencing cassava yield. J. Appl. Biosci. 26: 594-1602.

[15] Kenneth VAR (2011). Evaluation of three cassava varieties for tuber quality and yield. Gladstone road Agricultural Centre Crop Research Report 4: 12. 